\title{
Parenting Program in Guiding Children to Learn through Online Learning
}

\author{
Ihat Hatimah* \\ Community Education Department, Faculty of Education \\ Indonesia University of Education \\ Bandung, Indonesia \\ *ihat.hatimah@upi.edu
}

\begin{abstract}
The Covid-19 outbreak around the world has had an impact on various aspects of life, one of which is the education process, especially through face-to-face learning. Based on these problems, a policy emerged that learning changed from face-toface to learning at home via online (in the network). Based on this problem, requires parents to be able to guide their sons and daughters to study at home. This is a problem for parents who are not ready, because guiding children to study at home requires certain skills and skills, so that parents are able to use various appropriate strategies in guiding their sons and daughters to feel comfortable studying at home. The purpose of this study is to get an idea: 1) Readiness of parents in guiding her son learn through online, 2) Obstacles perceived parents in guiding her son learned through Online, 3) Impact of learning online to the habits children learn through Online. The method used is descriptive method, with interview data collection techniques, literature study and observation. Respondents were 10 families with the indicator having grade 1 or grade 2 school children. The findings of the study are: 1) The readiness of parents in guiding children during online learning was shown by increasing parental mastery of the use of learning technology, involvement in supervising the use of social media and conducting tutoring for children, 2) the obstacles faced by parents in guiding children to learn online, namely building a conducive learning atmosphere, building children's concentration and the complexity of the material provided by the teacher, 3 ) The impact of online learning on children's learning habits, namely creating a high enough dependence in the learning process, reduced children's learning independence and difficulties in measuring children's abilities.
\end{abstract}

\section{Keywords—parenting, Covid-19, online}

\section{INTRODUCTION}

The Covid-19 pandemic around the world has changed the order of people's lives in various aspects of social, health and community life [1], one of which is in the educational process, especially through face-to-face learning. Based on these problems, a policy emerged that learning changed from face-toface to learning at home via online (online). Utilization of network-based technology has been used to promote children's welfare [2-6].
Based on the problems that are felt around the world with the Covid-19 case, it requires parents to be able to guide their children to study at home. This is a problem for parents who are not ready, because guiding children to study at home requires certain skills and skills, so parents must be able to use various appropriate strategies in guiding their children to feel comfortable studying at home.

The education policy through Distance Education (Pembelajaran Jarak Jauh/PJJ) and E-Learning in Indonesia has a function listed in UUSPN No. 20 of 2003 (article 31 paragraph 2) [7] states that PJJ is a teaching and learning process carried out remotely through the use of various media communication. PJJ provides services to community groups who are unable to attend face-to-face or regular education and expands access and makes education services easier. PJJ makes a very large and useful contribution to the ongoing learning process, through PJJ it is demanded by all parties to take part in education through online learning using various media through technology. Apart from that, distance learning also poses big challenges for the industry in terms of technology implementation and human resource development [8].

One alternative to helping parents in guiding their children to study at home, is to make a temporary education policy through broadcasting an Indonesian national television channel based on KEMENDIKBUD.go.id 2020.

Online learning that is carried out in their respective homes, requires parents to be literate in technology and special skills in guiding their children. However, in reality not all parents have the ability and readiness to guide their children, so that panic arises among parents.

Based on these problems, the objectives of this study are: 1) to obtain data on the readiness of parents in guiding their sons and daughters to study at home through online, 2) problems faced in guiding their sons and daughters to study at home via online, 3) the impact of learning at home through online towards children's abilities. In carrying out its role in guiding their children, as parents must be able to follow the parenting process continuously through: 1) Continuous interaction between children, parents and society, 2) Children 
who have needs at the same time meet the important needs of parents, 3) Parents are responsible for raising children and meeting their needs, 4) Society acts as a strong support or pressure for children and parents.

To maintain the parenting process, Jarvis [9] states that parents are required to continue to want to learn throughout their life, this is based on the function of lifelong education as a force to motivate someone so that they can carry out learning activities based on encouragement and direction from themselves in a way think and act in and against the world of his life. To have the ability and sincerity, parents are required to continue learning to explore their potential in balancing learning for their children, so that the child feels comfortable in carrying out his learning.

\section{METHODS}

The approach used in this research is a qualitative approach with descriptive methods. This study provides an overview as suggested by Sugiyono [10], that a qualitative approach is used to reveal/describe phenomena and realities about the implementation of parenting programs in guiding children to learn through the network (online). Data collection techniques using interviews, observation and documentation study. The number of respondents taken was 10 families whose sons and daughters were still in first grade or second grade school.

\section{FINDINGS AND DISCUSSION}

Based on the results of interviews and observations, it was found that the learning activities in the researched and observed families varied in the use of the online discovery platform (application media), namely: through Zoom, WAG, Video, then supporting learning resources provided by the school, namely preparation. Module/Text Book.

\section{A. Readiness of Parents in Guiding Children}

Based on the results of interviews with all families who are respondents, in principle, they have a similar answer, namely being ready not ready to be ready to be ready to guide their sons and daughters to study at home through online learning (online) as a demand for conditions in the pandemic era. This is in line with Hadi's opinion [11], that online learning is a learning process that uses and utilizes the latest technology with learning activities that utilize networks (internet, LAN, WAN) as a method of delivery, interaction, facilitation and supported by various forms of learning services. Besides, through online learning the main role of the family is very influential, because according to Lestari [12] the family has a role in guiding their sons and daughters to study at home, namely:

- Knowing the development of technology, the use of technology, especially social media, which has a big impact on children

- Get involved directly and supervise children's activities on social media, be it YouTube, Facebook, WhatsApp, Instagram and others
- Actively providing understanding that is easily understood by children, responding to and responding back to the activities carried out by children and providing understanding for limiting the use of social media to choose which ones are good and which are not good at surfing the internet

In line with the opinion of Sardin [13], the role of the family in education is greater. Parents must serve as the child's first teacher, guide, teacher, and example. The impact of the Covid-19 pandemic on families must be able to create:

- The intensity of meeting between family members such as father and child, mother and child, and other siblings has begun to increase (interaction, communication, togetherness)

- Parents are the main figures (educators, priests, leaders)

- Discipline in maintaining personal hygiene and health

- Opportunity to worship with more families

Associated with the goals and objectives in parenting education for parents, namely:

- Increase parental awareness of the importance of childcare in education, so that parents care for their children and their education.

- Increase the knowledge and skills of parents in carrying out care and guidance for the interests of education for children, so that they are able to make plans for children's educational careers and future

- Bringing together the interests and desires of the family and the school, so that even if any problems occur, they can find solutions quickly

- Synchronizing and prioritizing the interests of educational care at home and at school, so that children do not experience dualistic parenting education patterns.

According to Slameto [14], there are three aspects that affect readiness, namely: physical condition, mental condition and emotional condition. Readiness is the willingness to respond and react. Online learning in the family can run effectively if there is participation from all parties, especially parents. McKenna and Strauser [15] stated that online learning preparation that parents as educators can do is to look for web resources or websites that offer:

- Plans and learning activities are carried out using the application

- Learning is done online

- Review of assessment data for each child

- Developing aspects of child development

- Routine activities of children at home online 
- Tools / materials that are easy to find around the house

\section{B. Obstacles Encountered}

Based on the results of interviews with respondents' families, there were problems in guiding their sons and daughters in online learning, namely:

- Having difficulty guiding because he is not a teacher, so he only guides when there is an assignment from the teacher

- Boredom arises from continuing to study at home, so the child only becomes an observer because it is through Zoom / WAG

- The children's concentration is broken because they are tired and unruly

- Discipline of children who pay less attention to the learning process

- Difficult material to follow in its entirety

Based on the research findings above, online learning that is carried out must create meaning for learners (in this case students), this is in accordance with the opinion of Munir [16] which states that online learning strategies must create meaningful learning which can be done through:

1) Ice breaker and opener: This activity aims to condition learners to focus on learning. Teachers need to take action by providing treatment in the form of actions to make learners active, a little game, show something that attracts learners. In online learning it is also necessary, in this case learners are shown in the form of images, or activities that make attention focused and ready to learn

2) Student expedition: When learners will learn via the web, the objectives to be achieved and the learning material to be studied have been presented first. Learning material that must be learned by learners is a kind of content map. In this section there is a useful or use of ways to use the web such as instructions for using this web to achieve goals. Also presented a list of activities carried out by learners while learning via the web.

3) Purposive Creative Thinking (PCT): identifies conflicts or problems in learning activities faced by learners that the learners can solve themselves through existing facilities, such as discussion forums or chats.

4) Peer to Peer Interaction $(P 2 P)$ : namely the use of cooperative methods in learning activities on the web. This has something to do with the previous activity, namely to overcome problems faced by learners whose solutions are sought through forum discussions.

5) Streaming expert: Not all the problems faced by the learner can be solved by yourself or discuss with other friends, but it is necessary also the opinion of the expert / specialist (expert) through video conferencing or just view the video that is already available in online learning (video streaming). In this activity it is also possible to have discussions between learners and experts/experts. If the web using the system synchronous then it's may occur.

6) Mental gymnastic: Learners carry out brainstorming activities, namely brainstormine activities that aim to achieve predetermined learning objectives. Learners collect a number of topics of interest to be discussed and conveyed to other learners.

According to Lestari [12], there are several strategies for assisting children in learning at home, namely:

- Create a comfortable and safe home atmosphere

- Create discipline in the child mentoring process

- Be consistent in the agreement made

- Give praise and criticism correctly

- Learning time expectations are adjusted according to the child's age

- Prepare materials and tools for playing as well as reading materials that support learning

- Involve the child in all activities at home

- Do play activities according to the wishes of the child

- Modeling in the sense of being a good example for the child

Parents play a very important role in educating, caring for, guiding their children so that they have a good personality as the parents want. There are also some academics that provide a definition of parenting that are simple parenting interpreted as parenting and education is education, based on the meaning of these two words can be understood that parenting education is parenting patterns associated with schooling itself. In simple terms, it can be said that parenting education is a job and skills for parents in caring for their children to develop all the potential that the child has brought from birth. Educational care is meant not only at school but at home as well as care in order to educate. Because in fact the duty of children's education is the obligation and responsibility of parents. This means that there needs to be an intervention program for families (parents of students) in utilizing online learning media so that learning outcomes can be achieved effectively. This is in accordance with the statement of Breitensein et al. [17] that:

"Evidence-based parent training interventions, although traditionally delivered face-to-face in group or individual format, are particularly suited to online adaptation. These programs provide parenting information that can be conveyed via on-screen text or narration, and use practical examples and role plays to model effective parenting strategies, which can be easily adapted to video format and delivered via the internet" [5,17].

Complementing the above opinion, Akhyadi [18] stated that the parenting program, which is one of the programs in 
strengthening family life and Indonesian society, provides one of the strengths in community life, especially early childhood development, parenting methods and communication patterns carried out by most of the community.

\section{Impact of Online Learning on Children's Learning Habits}

Based on the results of observations, documentation studies and interviews, children's abilities as a result of learning through online obtained the following data:

- Difficulties in measuring children's abilities

- Creating a high dependence on parents in the learning process

- Reduced children's learning independence

This is in line with the opinion expressed by Wang et al. [19] that online or distance education implies that students are physically distant from the instructor and require delivery methods. The interaction between students and teachers/parents is mediated by technology, and the design of the learning environment (for example, learning spaces) can have a major impact on learning outcomes, where information processing capacity is limited, and there is potential that a combination of learning modalities can lead to cognitive overload. For more details, Bower [20] explains the following:

"However, due to the COVID-19 pandemic, many students around the world had to transfer from face-toface instruction to an online learning environment in the middle of the semester. People have limited information processing capacity, and there is potential that combinations of learning modalities can result in cognitive overload, impacting the ability to sufficiently learn new information. Moreover, if students lack confidence in the technology they are using or do not feel a sense of cognitive engagement and social connection, the result may affect negatively the students' learning outcomes [20]',

Even though the data obtained is only on 10 families, if this is allowed it will have a negative impact on the abilities of the Indonesian nation's children. Because even though learning is carried out at home through online, learning outcomes must have targets, namely starting from the levels of Elementary School, Junior High School, and Senior High School.

\section{CONCLUSION}

During studying at home, family has a very strategic role. But in reality the family is not fully ready to accompany their children to study at home through online, because all families who become respondents feel that their educational background is not from teacher training.

To reduce the inability of parents in guiding children to learn through online, it requires training for families (Parenting Program) specifically on strategies and methods for guiding children, as well as a simple curriculum that parents can follow.

\section{ACKNOWLEDGMENT}

We would like to express our deepest gratitude to Department of Community Education for the research opportunity. We would like to also appreciate LPPM as the partner who has helped the research from the beginning till its completion

\section{REFERENCES}

[1] A.V. Dorn, R.E. Cooney and M.L. Sabin. "COVID-19 exacerbating inequalities in the US". Journal Lancet, 395. pp. 1243-1244. 2020.

[2] K.M. Baggett, B. Davis, E.G. Feil, L.L. Sheeber, S.H. Landry, J.J. Carta C. Leve. "Technologies for expanding the reach of evidence-based interventions: preliminar yresults for promoting social-emotional development in early childhood". Top. EarlyChild. Spec. Educ. 29 (4) 226-238. 2010.

[3] S. Baker, M.R. Sanders, A. Morawska, "Who uses online parenting support? Across-sectional survey exploring Australian parents' internet use for parenting”. J. Child Fam. Stud. 26 (3), pp. 916-927. 2017a.

[4] S. Baker, M.R. Sanders, K.M. Turner, A. Morawska, "A randomized controlledtrial evaluating a low-intensity interactive online parenting intervention, Triple POnline Brief, with parents of children with early onset conduct problems". Behav. Res. Ther. 91, 78-90. 2017b.

[5] S.M. Breitenstein, D. Gross, R. Christophersen, "Digital delivery methods of par-enting training interventions: a systematic review" Worldviews Evid.-Based Nurs. 11(3), pp. 168-176. 2014.

[6] P. Enebrink, J. Högström, M. Forster, A. Ghaderi. "Internet-based parent management training: a randomized controlled study". Journal Behav. Res. Ther., 50 (4) (2012), pp. 240-249. 2012.

[7] Undang Undang Republik Indonesia No 20 tahun 2003 tentang UUSPN

[8] L. Büth et al. Journal Procedia Manufacturing 23. Pp. 171-176. 2018; Training Concept For And With Digitalization In Learning Factories: An Energy Efficiency Training Case. Universität Braunschweig, Germany: Published by Elsevier B.V.

[9] P. Jarvis. Globalization, Lifelong Learning and the Learning Society: Sociological Perspective. London and New York: Routledge. 2007.

[10] Sugiyono. Memahami Penelitian Kualitatif. Bandung: Alfabeta. 2014.

[11] N. Hadi. "On-Line Learning sebagai salah satu inovasi pembelajaran". Jurnal Phytagoras. Vol 2, No 1, p. 12. 2006.

[12] L.D. Gunarti. Penguatan Keluarga dalam Pendidikan Anak Dimasa Covid 19. Universitas Negeri Surabaya. Webinar. 2020.

[13] Sardin. Kesiapan Keluarga dalam Mendukung Kesiapan Anak di Masa Pandemi (Covid-19) (Perspektif Sosio Ekologis). Webinar. 2020.

[14] Slameto. Belajar dan Faktor Faktor yang Mempengaruhinya. Jakarta: Rineka Cipta, 2010.

[15] McKenna \& Strauser. "Top Ten Tips For Student Teaching In Kindergarten". Jurnal STATE. Vol. 19 No 2. 2010.

[16] Munir. Pembelajaran Jarak Jauh Berbasis Teknologi Informasi dan Komunikasi. Bandung: Alfabeta. 2012

[17] T.K. Taylor, C. Webster-Stratton, E.G. Feil, B. Broadbent, C.S. Widdop, and H.H. "Severson. Computer - based intervention with coaching: An example using the Incredible Years program". Cognitive behaviour therapy, 37(4), pp.233-246. 2008.

[18] Akhyadi. "Program Parenting dalam Meningkatkan Kualitas Pendidikan Keluarga”. Jurnal Pengabdian Kepada Masyarakat IKIP Siliwangi. Vol.1 No 1.2018

[19] C.H. Wang, D.M. Shannon, and M.E. Ross. "Students' characteristics, self-regulated learning, technology self-efficacy, and course outcomes in online learning". Distance Education, 34(3), 302-323. 2013.

[20] M. Bower. "Technology-mediated learning theory". British Journal Education Technology, 50, 1035-1048. 2019. 